\title{
Animal Health and Welfare - Pig Production
}

\author{
By Pirkko Hämeenoja
}

Suomen Rehu Oy, Kuuselantie 75, SF-24260 Salo.

\begin{abstract}
Requirements of the organic pig farming create an opportunity to offer good life for animals. The space requirements give animals the possibility to exhibit species-specific behavior and provide them opportunity for more exercise. Bedding and roughage are important in helping to reduce production stress. The most difficult question in a veterinary point of view is how to manage the animal health care. Vaccinations, antibiotics and anthelmintic can be used in organic production but only in a limited way. A lot can be achieved with good management but there are still situations when the use of medicine is necessary. What is the amount of joint inflammations or liver spots to justify the use of medicine? The question has to be solved case by case. The profitability of the production is a crucial point in an organic farm because a poor economy is a great threat to animal welfare.
\end{abstract}

Organic pigs, animal welfare, natural behavior, housing, feeding, health care, and medications

\section{Introduction}

Consumers assume that organic livestock enjoy high standards of welfare. It is not known exactly what consumers believe animal welfare means while it is not easy to give a perfect definition for the concept (Verhoog 2000). One of the most frequently used definitions is given by Professor Broom in 1986: The welfare of an animal is its state as regards its attempts to cope with its environment (Broom 1986). Another well known definition is from early 70's by van Putten: Animal well-being is understood as living in reasonable harmony with the environment, physically as well as psychologically, meaning that the environment must be of such quality that it is within the adaptability of the animal involved" (van Putten 2000). It has been argued that animal welfare contains not only scientific but also value aspects. It is important to raise the questions of values and animal feelings in discussion, because most consumers probably assume those are the facts animal welfare deals with. In order to achieve measurable results it is, however, important to pay attention rather to animal health and behavior than to animal feelings.

\section{How to compare?}

When trying to evaluate how animals have succeeded in coping with their environment, the level of injuries, diseases, hormonal disorders and abnormal behavior would be good sources of information. Unfortunately there is not enough registered and comparable data of these available. The amount of medications could be studied but a low number can indicate either excellent health or lack of treatment and poor bookkeeping routines. Condemnations at slaughter tell about the level of health and welfare but - at least in Finland - competent reports are available only in big slaughterhouses. Organic pig producers are usually customers of very small butchers.

In Sweden and Denmark there are some investigations, which show that organic pigs have 
less condemnations than conventional pigs, except joint infections (Robertsson 2000) and liver condemnations (Alarik 1999, Mejer 1999).

\section{The farmer is important}

For the time being the statistics have not been able to prove a better welfare of organic pigs. However, the recommendations and requirements of conventional and organic production can be compared.

When doing this it must be remembered that proper requirements just create an opportunity to provide good life for animals, the rest is up to the farmer, the most important factor in the welfare of farm animals.

\section{Behaviour, space and roughage}

The main difference between conventional and organic animal husbandry is how much attention is paid to the natural behavior of animals. Nowadays the Nordic legislation of animal protection also takes natural behavior into account but in organic production it is far more important.

The space requirements and ban of confinement provide animals opportunity for more exercise. Better condition of muscles decreases for example the risk of MMA and joint diseases. When pigs have enough space to avoid higher ranked animals in the hierarchy, fighting and injuries are reduced. Group size is another important factor in minimizing restlessness, but there are no recommendations for that. Opportunity to exhibit species-specific behavior reduces the stress level, which helps to maintain good health.

Overcrowded pens are very common reason for tail biting, so we can expect less tail biting and boils in organic production.

Bedding and roughage are absolutely necessary for the welfare of pigs in many ways. Pigs are sensitive to variations in temperature because their ability to regulate the body temperature is poor. Without bedding they are disturbed as soon as temperature variation is more than 1$2{ }^{\circ} \mathrm{C} /$ day. Bedding raises the acceptable variation up to $5^{\circ} \mathrm{C}$.

Pigs also enjoy rooting and biting. It is more comfortable if they bite - for example - straw than each other. Tail-docking in not allowed in organic farms. That makes sense because tail biting is a good indicator of decreased welfare, and by removing the indicator, the reason for this situation is not removed. Roughage is also good for the function of intestines, and it diminishes the feel of hunger. For the farrowing sow, straw is necessary material for making the nest.

The possibility to carry out nestbuilding-behavior improves the sow's welfare. Farrowing without crate is good for the sow, but sometimes it can be fatal for piglets (Engblom 1999). Traditional farrowing pens are often too small for the free sows. In Switzerland new kinds of farrowing boxes for free sows have been developed but we don't have much experience of those yet in Finland. It's very important to find practical systems because high piglet mortality is acceptable neither from the welfare nor from economical point of view.

Pigs want to lie on solid floor and in organic norms at least $0.6 \mathrm{~m}^{2}$ solid floor per pig is required. It could be enough if pigs are slaughtered at a live weight of $100-110 \mathrm{~kg}$.

\section{Health and medicines}

The main idea of organic production is to prevent diseases by selecting the appropriate breeds, by offering them high quality food and proper environmental conditions. It has been suggested that smaller breeds with a colored skin should be used in order to avoid sunburns and to help swine to get rid of extra heat (van Putten 2000). Under Nordic conditions it may pose a greater risk for the animal welfare to im- 
port new breeds with new diseases than the risk our few sunny days of the summer can cause. In pig production we could pay more attention to the health status in the farm. In our small organic farms it would not be a problem to get rid of for example enzootic pneumonia and mange, which are important immunosuppressive diseases and quite easy to eradicate. The basic health status is far more important, when the number and the size of organic farms are increasing.

One of the basic ideas of organic farming is that prevention is better than cure. By using wider space standards and by limiting the number of animals in the farm we can reduce the infection pressure and diminish the need for antibiotics. The usage of roughage and straw as well as keeping animals free reduces stress of the pigs, which helps in maintaining a proper immunity. Early castration and teeth grinding are good methods, which save piglets from infections. Reluctance to administer medications in organic farming has been explained for example with holistic thinking (Lund 2000): we cannot think too much about a single animal if we have take care of environment. From an epidemiological point of view the situation is just the opposite. If we treat the sick animal quickly, the treatment result is better and the animal doesn't spread the disease to the other pen mates. Infection pressure is kept low and the others probably maintain a good state of health.

In the Nordic circumstances it is hard to find any other ways how organic farming could prevent pig diseases: the breeds are the same and excellent feed are used in conventional as well as in organic production. It has been found out in Finnish investigations, that organically produced grain from Middle Europe can include for example more heavy metals than conventional grain in Finland.

Vaccinations are used, above all against Erysipelas. Recommendations say that vaccina- tions should be avoided but can be used if needed. Being such a common and harmful disease it is compulsory to vaccinate against Erysipelas also from welfare point of view. For example in Sweden a lot of joint infections with pigs from KRAV-farms have been found. When studying 300 blood samples a positive correlation was found between antibodies against Erysipelas and joint infections (Robertsson 2000). Parvovirus is also so important economically, that it is very risky to run the farm without vaccination.

Pigs need some place for rooting which is one of the basic needs of them. Rooting helps against tail biting but paddocks are a very suitable environment for Ascaris suum, Trichuris suis and maybe also for other helminths. Mejer et al. (1999) studied the importance early infection of piglets with several helminths. They found out for example that a high infection level decreases the average daily weight gain before weaning (Mejer et al. 1999). In organic production it is assumed that changing the pasture every summer and having a cycle of five years is enough for controlling parasites. Outdoor pens increase the risk of parasitic infections (Baumgartner 2000), so often it is necessary to use anthelmintics regularly.

In organic production the access to medicine is more limited than in conventional production. In Finland the greatest difference is with anthelmintics. It is a big challenge to organic production to reduce the use of medications without reducing the animal welfare. Alternative treatments of diseases are also recommended. As we know from human medicine there is a great variety of treatments, which are sold under this title. A lot of them have no scientific justifications.

The new regulations of feeding organic pigs increase the time to market of finishing pigs by about two weeks. When pure amino acids are banned, the total protein content of feed in- 
creases. It also leads to greater ammonia concentration in the air causing a risk for the health of the lungs. The increased production time itself is hardly a welfare problem, if we can handle the ammonia. Another critical question is the increasing emissions of nutrients to environment.

\section{Welfare needs money}

One of the most important questions in the welfare of organic pigs is the profitability of production (Sundrum 2000). Poor economy is a great threat to the animal and its owner's welfare.

\section{References}

Alarik M: Dokumentation av ekologisk grisproduktion. Produktionssystem och produktion resultat i sex ekologiske grisebesättningar under period, 1997-1999, Documentation of organic pig production. Production system and production results in six organic pig farms during 1997-1999, Hushållningssällskapet I Stockholms och Uppsala län, Uppsala, 30 pp, 1999.

Baumgartner J, Leeb T: Husbandry and Health of Sows and Piglets on Organic Farms in Austria, Proceedings $13^{\text {th }}$ IFOAM Scientific Conference, page 361, 2000.

Broom DM: Indicators of poor welfare. Br.Vet.J., 1986, 142, 524-526.

Engblom L: Smågrisar ute och inne, Piglets outdoors and indoors, Forskningsnytt, December,1999, 8, page 3 .

Lund V: 2000. Is there a such a thing as "organic" animal welfare? http://www.veeru.reading.ac.uk/ organic/proc/lund.htm 2000.
Mejer H, Thamsborg SM, Roepstorff A, Eriksen L: Økologiske grise får mange indvoldsorm-men hvad betyder de for dyrene, Organic pigs have many intestinal worms, but what is the influence of them on animals Forskningsnytt, December, 1999, 8, 15-18.

Robertsson JA: Svenska Djurhälsovården: Hälsoprogram för ekologisk djurhålling, Health program for organic animal husbandry. Forskningsnytt, February, 2000, 1, page 8.

Sundrum A Trangolao A: Conversion of specialized pig farms and the implications on nutrient and economic balance, Proceedings $13^{\text {th }}$ IFOAM Scientific Conference, 2000, page 371

Van Putten: An etological definition of animal welfare with special emphasis on pig behaviour. http://www.veeru.reading.ac.uk/organic/proc/va nP.htm.Updated 12.4. 2000

Verhoog $H$ : Defining positive welfare and animal integrity http://www.veeru.reading.ac.uk/organic/ proc/verho.htm.Updated 12.4. 2000.

\section{Sammandrag}

Konsumenterna anser allmänt att grisarnas välbefinnande i ekologisk produktion är hög. Låg djurtäthet och betoningen av djurens naturlig beteende ökar ekologiska djurs välbefinnande. Infektionsrisken är liten och beteendestörningar är också sällsynta. Det finns inte tillräckligt produktionsdata om ekologisk produktion för att kunna jämföra med konventionell produktion. Utredningar gjorda t.ex. i Sverige och Österrike visar att båda endo- och ektoparasiter är problem i ekologisk grisproduktion. Utfodringen av unga grisar, bruk av endast alternativa läkemedel och osäker ekonomi medför också risker för djurens välbefinnande. 